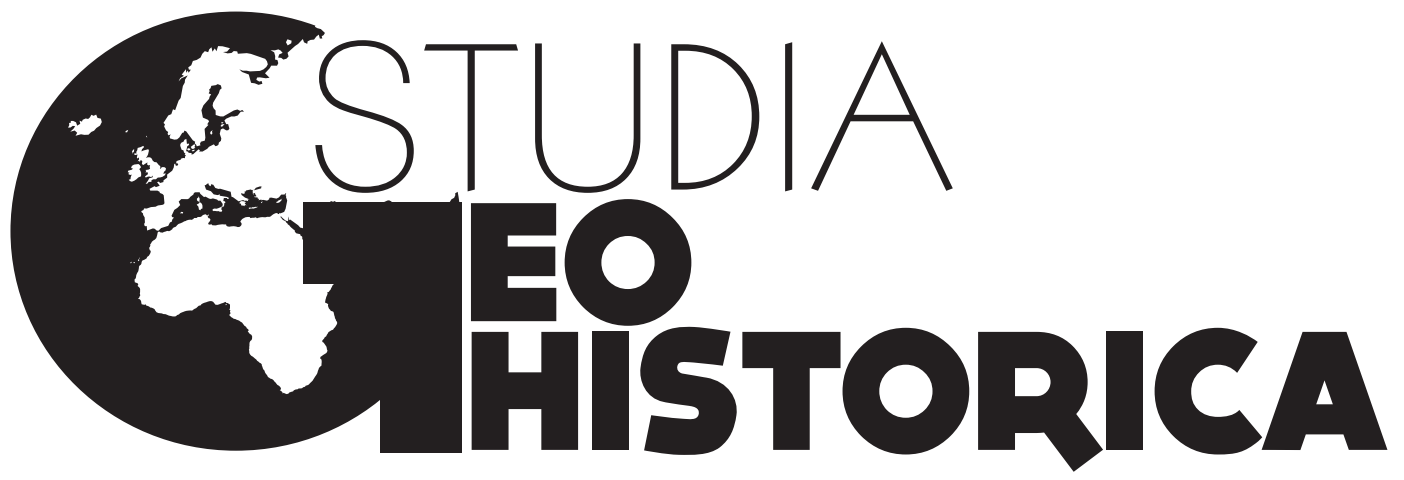

NR 06|2018 ROCZNIK HISTORYCZNO-GEOGRAFICZNY 


\section{Contents}

A note from the editors 5

International Conference of Historical Geographers

Diogo de Carvalho Cabral

Landscape and Letterscape in Early Colonial Brazil 7

Karen M. Morin

Prisoners and Animals: An Historical Carceral Geography ... 28

Humphrey Southall

Spaces, Places, Features and Units: Web-Enabling Historical Geography. 39

\section{Articles and theses}

Agnieszka Latocha, Dominik Nowakowski

Sources and Methods Used in the Reconstruction of Settlement Networks:

An Archaeological and Geographical Perspective on the Example of Silesia

Marek Sobczyński

Polish Geographical Survey of Borders until 1945

\section{Roman Czaja}

Historical Atlas of Polish Towns. Between Source Edition

and the Cartographic Presentation of Research on the History of Towns

\section{Piotr Guzowski}

Economic Geography of Poland in the Period of Growth (14-16th Century)

in the Polish Historical Study

Dzmitry Vitsko

Historical Cartography in Belarus (Studies on the Administrative Division,

Borders and Population of the Grand Duchy of Lithuania)

Henryk Rutkowski

A Few Comments on the Historical Borders in Poland

Bogumił Szady

Historical Cartography of Confessions and Religions in the Polish-Lithuanian

Commonwealth: Between Historical Geography and Spatial History 136 


\section{Tomasz Figlus}

The Past and Present of Historical Morphology of Rural and Urban Forms in Poland

\section{Maryana Dolynska}

Some Principles of Interdisciplinary Investigation

for Recreating the Historical Topography of Urban Spaces

\section{Atlas Fontium}

Atlas Fontium

(Marek Stoń)

Tomasz Panecki, Tomasz Związek, Grzegorz Myrda

The Spatial Database Development for Research on Settlements and Afforestation in Nowy Tomyśl Plain in Early Modern Times

Marek Słoń, Urszula Zachara-Związek (eds.)

The Court Records of Wschowa (1495-1526). Digital Edition

\section{Reviews and discussions}

Deutscher Historischer Städteatlas, Nr. 5: Dortmund, Hrsg. Peter Johanek, Jürgen Lafrenz, Thomas Tippach, Münster 2018 (Michał Stomski) 


\title{
The Court Records of Wschowa (1495-1526). Digital Edition
}

\author{
Editors: Marek Słoń, Urszula Zachara-Związek
}

Elaborated by: Arkadiusz Borek, Witold Brzeziński, Michał Gochna, Emil Kalinowski, Joanna Karczewska, Paweł Klint, Krisztina Rábai, Michał Słomski, Konrad Szuba, Tomasz Związek*

(http://atlasfontium.pl/index.php?article=wschowa)

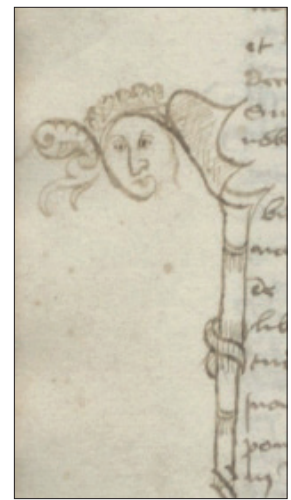

This publication, consisting of a text and a web application, proposes a new approach to the method of editing historical sources. It does not contain a full reading of the manuscripts it discusses, but at the same time it provides the user with complete text, and several tools - the result of the authors' research work - which make using the manuscript much easier. The source itself and the results of the work are presented in three interconnected formats: tables, a GIS map and high-quality digital scans of the records. The first table contains a list of entries together with basic information about them, and a full text of some of the entries. The second table constitutes a joint index of geographical and personal names and other key terms.

\section{The Court Records ("Acta castrensia") of Wschowa, 1495-1526: The origin and course of the project}

The project was born on March 20 $0^{\text {th }}, 2014$, in the Department of Historical Atlas during a discussion about three Ph.D. theses to be written in the team. Each of the proposed theses dealt with the district or archdeaconry of Kalisz (the borders of these two territorial units largely overlap) in the $15^{\text {th }}-16^{\text {th }}$ century ${ }^{1}$, and each requ-

* Marek Ston and Urszula Zachara-Związek are the editors of the publication, others are given in alphabetical order. The details on the work division can be found further in the text. The works on the edition and this text was ired a research in a source base comprising several thousand pages of the court books. Such tremendous amounts of work would lack sense if conducted for the purpose of only one study. It was concluded that it should be coupled with indexing the sources, but that would require more people, and consequently more funds. As such, it was decided that three applications to the upcoming Preludium funding scheme by the National Science Centre (Pol. Narodowe Centrum Nauki; hereafter: NCN) should be submitted. Eventually, it transformed into a large scholarly enterprise and required necessary preparations in several areas. A team of people interested in the work had to be gathered and the skills of its members had to be tested. Also, the very method of editing had to be designed and verified. The intention to achieve the most complete result and the possible speed of carrying out the project, which could only be measured in practice, had to be balanced. Additionally, the result had to be presented in a way that would convince the NCN experts what the assumed and possible goal was. The time was

financially supported by the cities of Leszno and Święciechowa (indexing work) and Silesian University in Opava (Project Nr. P01-2016-18; cooperation with Krisztina Rábai).

${ }^{1}$ M. Gochna, Granice państwowych jednostek terytorialnych, in: Wielkopolska w drugiej połowie XVI wieku, red. K. Chłapowski, M. Stoń, Warszawa 2017 (Atlas Historyczny Polski. Mapy Szczegótowe XVI wieku, 4), p. 4664; A. Borek, Granice jednostek administracji kościelnej. A: Diecezja gnieźnieńska i wtocławska, in: Wielkopolska, p. 65-91. 
of the essence as the deadline for applying was in less than three months.

It was decided, that it would be best to publish a book of a small territorial unit which would count less than 500 pages and cover the turn of the $15^{\text {th }} / 16^{\text {th }}$ century, preferably from the voivodeship of Poznań - so as to benefit from advanced dictionary works on the historico-geographical dictionary of Polish lands in the Middle Ages (Pol. Stownik historyczno-geograficzny ziem polskich $w$ średniowie$c z u)$ for the said voivodeship ${ }^{2}$ and thus, connect this task with the team's current project. Based on these criteria, the first court book of Wschowa Land was chosen. That day, the idea was shared with Tomasz Jurek, who was responsible for the works on the dictionary. What followed was a lively discussion about various aspects of the project and the very nature of source editing. On March $26^{\text {th }}$, the entire court book kept in the State Archives in Poznań was viewed, photographed, and selected volumes of Kalisz records, as well as manuscript indexes of court books were browsed. The plans had also been discussed with the director of the archives, Mr. Henryk Krystek. The following day, possible sources of funding for the project were searched for among the authorities of the cities of the former land of Wschowa, including its capital. The next day, that is March $28^{\text {th }}$, it was decided that the indexing of court books would be carried out in three stages, and that subsequent stages would depend on the result of the preceding stages and obtaining funds:

1. The court book of Wschowa, with the support of local authorities;

2. Selected court books of Kalisz Land: court books (acta castrensia, acta terrestria, end of the $15^{\text {th }}$ and end of the $16^{\text {th }}$

2 The historico-geographical dictionary of Polish lands in the Middle Ages: Stownik historyczno-geograficzny ziem polskich w średniowieczu, red. T. Jurek (http://www.slownik.hpan.edu.pl/index.php, access: April 24, 2018). century), and consistory records (beginning of the $16^{\text {th }}$ century), in total around 20,000 pages, within the scope of the three Preludium grants;

3. Converting the court books and surviving manuscript indexes from Greater and Lesser Poland (several thousand index volumes for a series of several million manuscript pages) into a uniform database and connecting it with the digital facsimiles, with the funding under National Programme for the Development of $\mathrm{Hu}-$ manities (NPRH), a commissioned project, or from another source.

It took about three weeks to gather the main team of 10 people. Particularly challenging was to find people with sufficient experience with court books from the period in question, proficient in reading gothic cursive, and willing to devote their own time to unpaid work with a very short deadline. Finally the team comprised the Historical Atlas of Poland employees along with their previous cooperators ${ }^{3}$. Finally, on April $16^{\text {th }}$, the division of work took place.

In the meantime, scans of the manuscript ${ }^{4}$ were obtained and indexing began. Within a month, the first reading was ready and entered into spreadsheets. Unfortunately, contact with an IT specialist responsible for the application was lost, and, on May $20^{\text {th }}$, another specialist, Kristian Kann, was commissioned with the task. At this stage, the project was presented four times: on May $21^{\text {st }}$, in the Department of Medieval Studies in the Institute of History, Polish Academy of Sciences, the next day during the M.A. seminar of Prof. Maria Koczerska at the Institute of History (University of Warsaw), and on May $27^{\text {th }}$, in Wschowa and Leszno. As a result of the latter presentations, a sum of PLN 10,000 was assigned to the project from the mayor of Wschowa, the president of Leszno, and the head

\footnotetext{
3 A detailed description of said works can be found at the end of this text.

4 The scaning was conducted according to the procedures of the State Archives in Poznań.
} 
of Święciechowa municipality, the three historical towns of Wschowa land. The working version of the indexing application was ready at the end of May, and after a week of tests, marking entries and key terms on the manuscript could finally begin. In mid-June, thanks to the support of Bogumił Szady (Catholic University of Lublin), the work from separate spreadsheets (one for each person) was transferred to one database. Applications for the financing of the edition of Kalisz court books were also submitted at the time. On July $15^{\text {th }}$, marking key terms on the manuscript facsimile was concluded. Topographic base was prepared by Tomasz Panecki (Institute of History, Polish Academy of Sciences) with the use of the settlement network already marked on the map by Catarina Seeger (University of Würzburg). At the same time, members of the team were busy collecting excerpts from the books, preparing a full-text reading of chosen entries, identifying individual scribes (Joanna Karczewska and Witold Brzeziński), preparing introductory material about the sources (Brzeziński), and writing down the rules of editing determined in the course of the works (Marek Słoń). This description was written on the same day, and Szady adjusted the web-GIS application and put it on the internet site - the working version was made available in the "Atlas of Sources and Materials to the History of Old Poland". Prof. Barbara Czopek-Kopciuch, the head of the Onomastics Department at the Institute of Polish Language, Polish Academy of Sciences, offered her support in verification of the normalised forms of names and surnames.

The decision to publish an unfinished work was taken for several reasons. The most important is the belief that publishing historical sources is a process which is initiated, brought to a certain point, but not finished. An open form of editing that invites users to join the process is proposed, which assumes and promotes critical remarks, e.g. specific paleographical corrections, errors in functionality, or any supplements, like a new group of key terms, German version of site names, etc. Therefore, others are welcome to submit their remarks through the application, or to contact the Department of the Historical Atlas directly. Positive comments can also prove valuable.

The end of work on the Wschowa records had been planned for 2014. However, an obstacle was the withdrawal of the city of Wschowa from the promise of financing the project. There have also been critical remarks of users, which led to engaging in a new redaction of all Latin passages. This work was done by Urszula Zachara-Związek. In addition, in collaboration with Krisztina Rábai, she supplemented the source commentary with codicological analysis.

\section{The Court Records of Wschowa (1495-1526): The sources}

Acta castrensia (Civil court records, or court books), written down in Polish lands in the late medieval and early modern period, are an extremely valuable source for research on Polish society of that time. This mostly concerns the nobility, but it is also true for other social classes. The records offer a particularly useful insight into the law and judicial system of the period, ownership relations, as well as various aspects of economic life, family relations, relations between neighbours, and between social classes.

The abundance of information found in the records - still not fully utilised in historical research - is the result of the specific nature of the institution by which they were created. This was the starosta's court or iudicium capitanei (later iudicium castrense), and later also the officium castrense (the office attached to the court), formed in the course of the transformation of the starosta's function. Most of the 
entries in the books are connected with the activity of the iudicium and officium castrense. They also contain contracts and statements about finances and wealth, both temporary, and perpetual. At the beginning of the $16^{\text {th }}$ century, also because of the growing number of entries, particular series of entries were separated - on the basis of documented activity. However, the oldest books do not have this division, all types of entries were made in one book. It is only in the records of the starosta general of Greater Poland, that perpetual transactions were singled out in a separate series from the very beginning (resignationes) $)^{5}$.

The oldest surviving acta castrensia come from Lesser Poland and central Poland (the old voivodeships of Łęczyca and Sieradz), where they were written down already in the 1390s. In Greater Poland the oldest known surviving records are the records of the burgrave of Kalisz castle from 1418. Next in chronological sequence are the records from Kościan and Nakło from 1432, and Poznań (1434) ${ }^{6}$.

\footnotetext{
5 Janusz Łosowski provides a synthetic presentation of the development and functioning of the castrensis chancellery, as well as the castrense iudicium and officium in Polish lands in late medieval and early modern period. See J. Łosowski, Akta sądów i urzędów szlacheckich w XIV-XVIII wieku, in: Dyplomatyka staropolska, red. T. Jurek, Warszawa 2015, p. 253-338; Kancelaria grodzka chełmska od XV do XVIII wieku. Studium o urzędzie, dokumentacji, jej formach i roli w życiu spoteczeństwa staropolskiego, Lublin 2004, passim. Here there is also a list of earlier bibliography. Among them, the most important in terms of history and functioning of starosta's courts (iudicia castrensia) are works of Antoni Gąsiorowski: A. Gąsiorowski, Urzędnicy zarządu lokalnego w późnośredniowiecznej Wielkopolsce, Poznań 1970; idem, Tak zwane prawo wieczności w dawnej Polsce, "Czasopismo Prawno-Historyczne", 22 (2), 1970, p. 31-58; idem, Początki sądów grodzkich w średniowiecznej Polsce, "Czasopismo Prawno-Historyczne", 26 (2), 1974, p. 57-79; idem, Starostowie wielkopolskich miast królewskich w dobie jagiellońskiej, Warszawa-Poznań 1981. For the history of castrensia chancelleries in Greater Poland see mainly works of Janina Bielecka: J. Bielecka, Organizacja i działalność kancelarii ziemskich igrodzkich wielkopolskich XIV-XVIII w., "Archeion", 22, 1954, p. 129-152; eadem, Kancelaria grodzka wielkopolska w XVI-XVIII wieku, "Studia Źródłoznawcze", 1, 1957, p. 119-153; and the basic work: eadem, Inwentarze ksiąg archiwów grodzkich i ziemskich Wielkopolski XIV-XVIII wieku. Województwo poznańskie, kaliskie, gnieźnieńskie, inowrocławskie, Poznań 1965. For information about court books in the State Archives in Poznań see also Z. Wojciechowska, Księgi sądowe wielkopolskie z okresu I Rzeczypospolitej w zasobie Archiwum Państwowego w Poznaniu, "P0znański Rocznik Archiwalno-Historyczny", 5, 1998, p. 11-32.

6 A. Gąsiorowski, Początki, p. 68, 71 .
}

The acta castrensia from Wschowa dating back to the $15^{\text {th }}$ and $16^{\text {th }}$ centuries (no. Gr. 1) are the first surviving court books from this area, but not the first created in Wschowa. A 1665 inventory known as Catalogus seu regestrum mentions earlier records, something - according to the scribe's own words - "resembling a little register". It contained entries from 1432$1512^{7}$. In the surviving acta castrensia of Wschowa, in their current shape, the chronological scope of entries encompasses the period from 1495 to $1526^{8}$. The records begin with the entry: "Acta capitaneatus venerabilis domini Alberti Gorsky scolastici Wladislaslauiensis et cancellarii Poznaniensis ecclesiarum protunc capitanei wschouensis super anno domini 1495 per me uero Martinum de Bidgostia eo tempore notarium arcis acticata" ". The last entry is dated on May $28^{\text {th }}, 1526^{10}$.

Between 1495 and 1526 the starosta's office in Wschowa remained in the hands of the members of the Gorrski family from the house of Łodziowie. They were the sons of the castellan of Ląd and starosta of Wschowa (since 1462) Wojciech Górski (d. 1494): Wojciech, Jan, Piotr and Maciej. The first two were clergymen. Wojciech (d. 1507), as pointed above, owned a benefice in the cathedral chapter of Włocławek, and was also the chancellor of the Poznań cathedral chapter. Jan (d. 1533) was the archdeacon and officialis in the cathedral chapter Poznań. Both were also secretaries of the royal chancellery. Piotr, who died between 1538 and

\footnotetext{
This inventory is Catalogus seu regestrum librorum resignationum, inscriptionum, iuditorium, relationum et aliarum recognitionum, written down in the acta castrensia of Wschowa 145 (State Archives in Poznań, Wschowa Gr. 145, ff. 773-782), see J. Bielecka, Inwentarze, p. 370, footnote 5).

8 Entries about two earlier documents can also be found in the book. On sheets 104v-105 (p. 206-207, entry f104 1) there is a document registered issued by Kazimierz Jagiellończyk on July $21^{\text {st }}, 1459$. The other document, dated June $12^{\text {th }}, 1422$, was issued by Władysław Jagietto and registered in an entry from 1526 ( 1195 _, text of the document on sheets 195-196 (p. 381-383).

9 Entry f1 1 .

10 Entry f195_1.
} 
1540 , became the castellan of Nakło in 1503. He also held the starosta's office in Człuchów (until 1508). The youngest, Maciej (died after 1540), did not hold any dignity ${ }^{11}$.

In terms of content, entries in the acta castrensia of Wschowa represent four main categories singled out by Janina Bielecka for entries in the Greater Poland records, pertaining to the old chancellery practice. In accordance with the terminology used at the time, she called them resignationes, inscriptiones, relationes and decreta ${ }^{12}$. The first category encompasses legal actions connected with perpetual change in assets, including sale contracts, donations, dowry payments and dowry arrangements. According to Bielecka in this category there are also acts of sale subject to a right of repurchase (the so-called wyderkaufy or wyderki $)^{13}$. The inscriptiones category contains entries documenting bilateral temporary transactions, like various loans, securities, leases, and unilateral statements (e.g. renunciations of rights to sums of money). The category of relationes contains mostly statements of court ushers (e.g. about calling parties in trial, about carrying out or objecting intromissio), as well as testimonies of people appearing in the court, in both contentious and non-contentious matters. The last category, decreta, contains entries documenting contentious proceedings before the starosta's court, including decisions about the adjournment of trials, verdicts and adjudicated fees for failing to appear in court.

At present, the oldest surviving acta castrensia from Wschowa are kept in the State Archives in Poznań under signature "Wschowa Gr. 1". It is a 194-sheet

\footnotetext{
11 In the case of Wojciech and Jan only the most important offices are listed For information about their brothers as starostas of Wschowa see A. Gąsiorowski, Starostowie, p. 69, and about their father: W. Brzeziński, Krag rodzinny kasztelana lędzkiego Wojciecha Górskiego herbu Łodzia († 1494), "Studia z Dziejów Średniowiecza", 18, 2014, p. 15-51.

12 J. Bielecka, Inwentarze, p. XIII-XV.

13 Ibidem, p. XIV.
}

(388-page) paper manuscript in folio format, and the condition of the sheets can be described as good. Only some of the first sheets of the book are scrappy on the edges, the first sheet being in the worst state. Relatively few sheets have small stains. The leather cover of the volume, most probably dating back to the $16^{\text {th }}$ century (which can be demonstrated by its renaissance ornaments), is damaged, in many places the leather is worn. There are also defects on the back and on the edges of the cover. In the middle of the front cover there is a sheet of paper, probably stuck on in the $17^{\text {th }}$ century, containing the title and (incorrect) date of the volume. Each sheet of the book has been numbered earlier (sheets 1-196v), but the numbers $88-88 \mathrm{v}$ and $164-164 \mathrm{v}$ are missing. The book was paginated before scanning, empty sheets were omitted (ff. 88-88v, 120v, 144v, 164-164v, 181, 187v). According to Bielecka, the first 36 sheets are rough copies. In this part of the volume there is chronological disorder. Only at sheet $37 \mathrm{r}$ does the fair copy begin, with entries starting in 1502 . Bielecka also noted that sheets containing entries from 1495 and 1496 could have been added to the book when it was being bound at the end of the $17^{\text {th }}$ or in the $18^{\text {th }}$ century, as the remaining part of an earlier book ${ }^{14}$. However, this is an incorrect view and results from a misreading of a gothic form of the numeral 5 in the date 1495 on the f. 1 as 7. Moreover, f. 1 is a title page, while on the f. 10 , where entries from 1497 start from, there is no distinct heading informing readers about the date of a court session. But the clinching argument is that the entries from 1497 start in the middle of the quire II, so the sheets containing entries from previous year could not have been added later.

The volume consists of 18 quires covering a different number of sheets - from

14 Ibidem, p. 370, footnote 5 . 

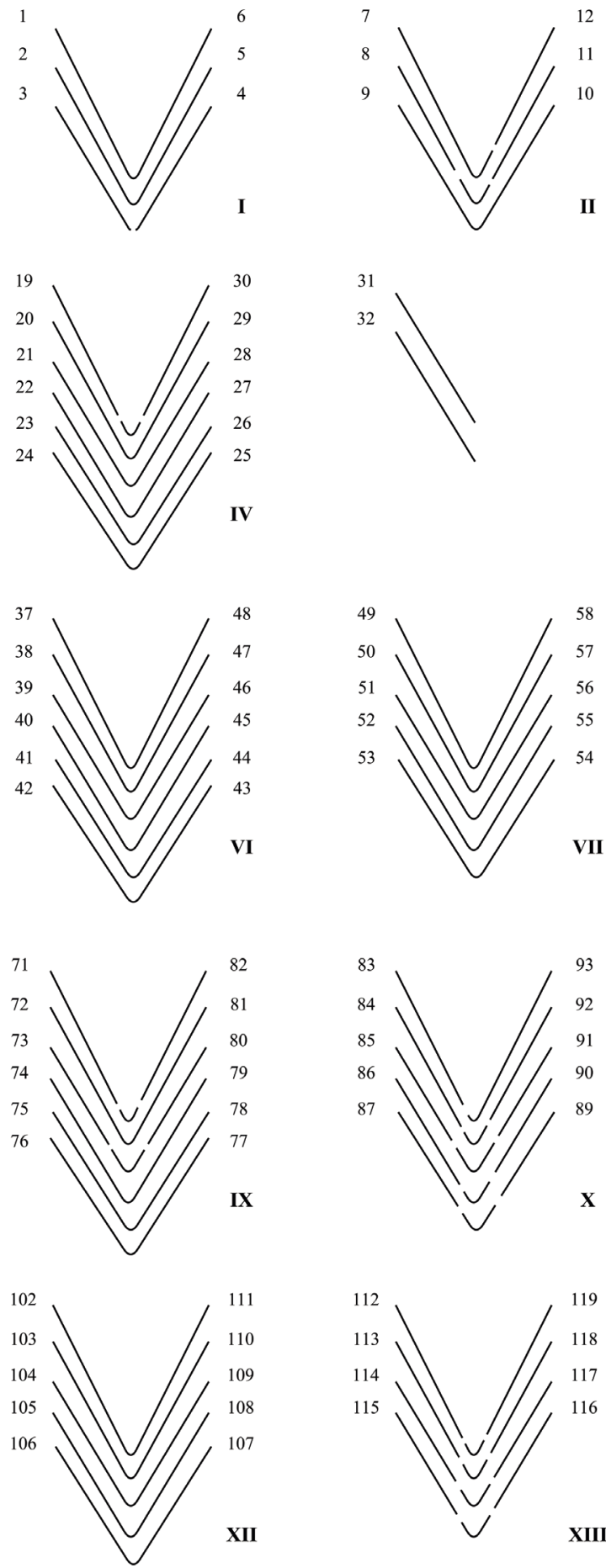
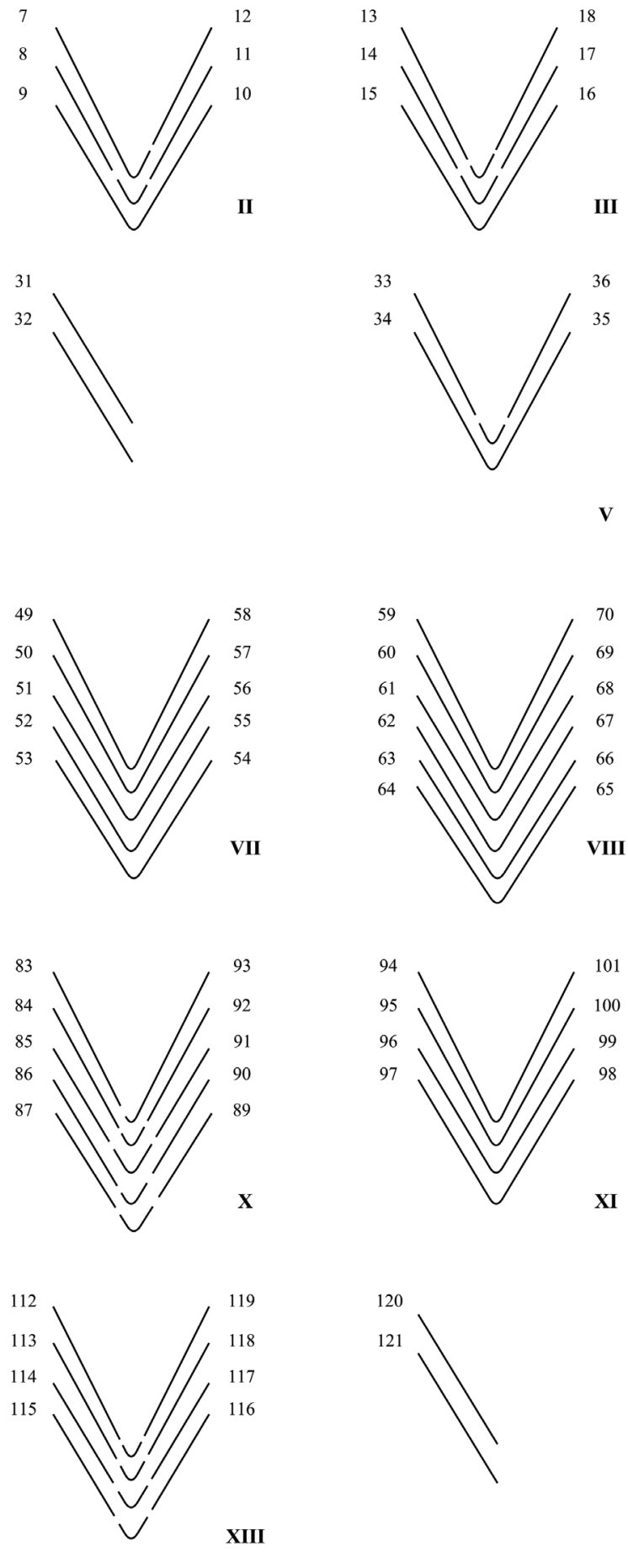

V
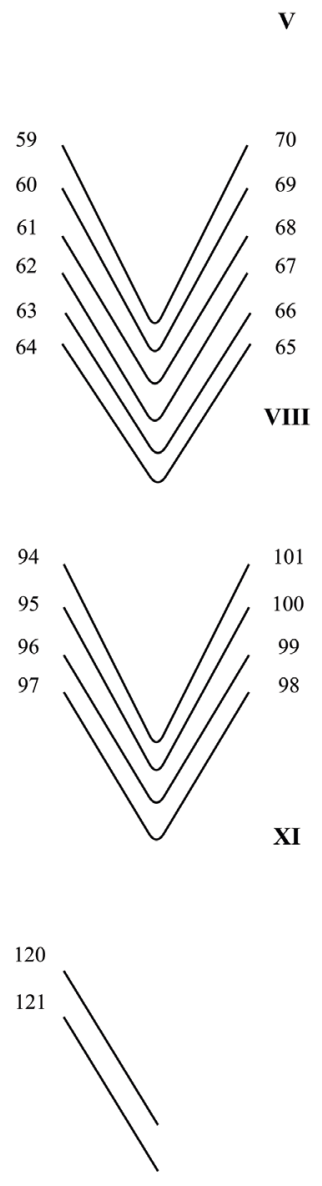

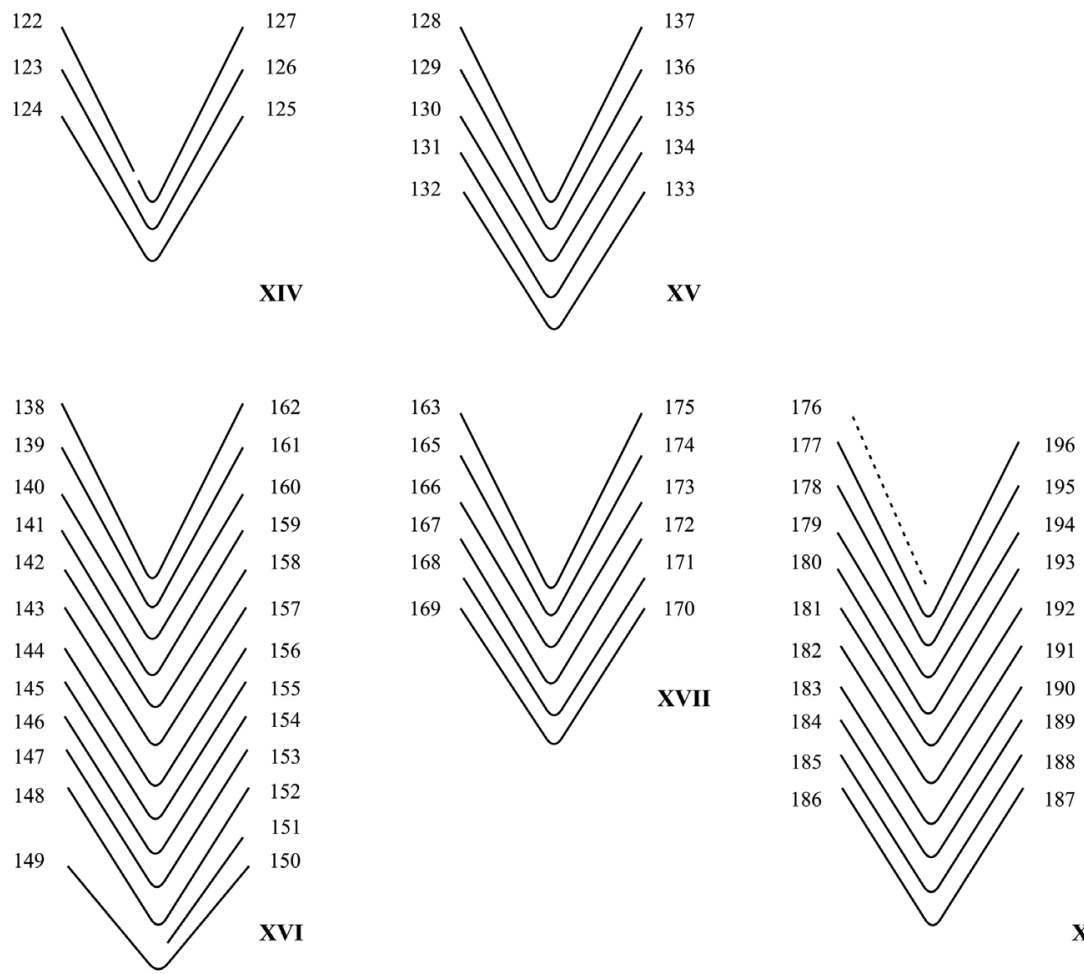

XVIII

Fig. 1. Layout of the court book of Wschowa

$2+2$ to $12+12$ leaves, with thicker ones being placed in the second part of the volume. There are also loose sheets, inserted between the quires or between the leaves of one quire. The last quire is incomplete, missing the f. 197, which should be the second half of the f. 176, and in which the entry from the f. 196v should be completed. The current layout of the book is as presented in the figure 1 .

Many folia were cut out of their quires and re-pasted in, not always in the correct place, as is evidenced by discontinuities in the content of entries (no continuation between f. $8 v-9$, f. $18 v-19,82 v-83$, $115 \mathrm{v}-116)$. Uncompleted records except from one (the entry from $\mathrm{f} .18 \mathrm{v}$ is completed on $\mathrm{f}$. 33) have no continuation in the remainder of the volume. Folia 120121 are about $1 \mathrm{~cm}$ smaller than the others. The f. 120 was sewn between quires and sheet 121 was stuck to it. The process of cutting out and re-pasting the sheets and the process of repairing damaged bifolia should probably be dated back to the $16^{\text {th }}$ century, because the same kind of paper was used for writing the text of the volume and for pasting cut sheets. Fragments of filigrees can be seen on those pieces of paper sheets ${ }^{15}$.

Analysis of watermarks also revealed a disorder in the layout of the quires. Normally, one watermark is apparent on

\footnotetext{
15 See e.g. f. 72, where on the strip of paper a fragment of filigree depicting a snake coiling a cross is to be seen, and $\mathrm{f}$. 74 , where on the strip of paper there is probably a fragment of an ox head.
} 
a bifolium (as the bifolium is folded, the watermark is on one folium, the other folium is without mark). Quire X, 5+5, including ff. 83-93 (there is no f. 88), consists of cut-out and re-pasted sheets. Albeit 83-93 is a bifolium, there are two identical watermarks, depicting an ox head with curved horns, with a rod ending in a Latin cross protruding from the top of its head, with a serpent twined around the rod. If the paper of this bifolium was produced in a mould, than the wires of the watermarks had to be pressed into the paper on one side and by folding it watermarks have to be seen impressed from one direction, but by examining bifolium 83-93, we can see that the watermarks were pressed from opposite directions. Bifolia 86-90 and 87-89 do not contain any watermarks. Consequently, these bifolia were glued together by chance and were not produced as one sheet of paper on one mould. Interestingly, no discontinuity of records was observed within this quire; there is only no continuation between quires IX and X. This would mean that this could be the original form of this quire, demonstrating that the staff of the starosta's court used some kind of waste paper, loose sheets and their halves to create quires of volumes.

On the sheets of the volume 96 filigrees were identified. Among them the most frequent symbol is a fauna motif, an ox head, represented by 60 watermarks, which is more than $60 \%$. There are many different versions of this main symbol, but the most popular is an image of an ox head with a rod ending in a Latin cross protruding from the top of its head, with a serpent twined around the rod. In the other sheets of the volume there are also 19 filigrees that depict a boar, 7 - with monogram $W$ with a crown, 6 containing the image of a heraldic shield with an arrow (or a sword or a cross), 2 depict an image of an anthropomorphic figure with long hair on a heraldic shield,
1 - a three-leaf clover and one contains a crown with a diadem, a cross and a star.

Sheets in the entire book have deletions, corrections, notes on the margin of and inside the text, as well as crossing outs when an entry was annulled. Entries without a heading were usually given a title later that informed the reader about the type of a given case.

The writing is usually legible. Fifteen different hands were identified. They are marked from $A$ to $O$, and listed below.

The highest number of scribes appears in the first part of the book (f. 1-36v), encompassing entries from 1495-1502, where 10 different hands were distinguished. Entries from the remaining period were made mostly by three scribes (I, $\mathrm{K}$ and $\mathrm{O}$ ), of which two are known by name. These are Tobiasz Rogaliński (I), who worked between 1502 and $1507^{16}$, and Stefan Rudawski (K), between 1507 and $1511^{17}$. The name of one of scribes entering records in the first part of the book is also known. This is Marcin of Bydgoszcz (A), who worked between 1507 and $1511^{18}$. Other scribes unfortunately remain anonymous.

In the volume some errors in the dating of entries are found. Some of them could be explained by a scribe's mistake, resulting from the mixing up of Polish and Latin names of the days ${ }^{19}$, and some of them were probably caused by inattention of a scribe, who made a fair copy of an entry, perhaps after a long time ${ }^{20}$. But those cases are few.

\footnotetext{
16 Mentioned in two entries: $f 37 \_1$ and f40v_1.

17 Mentioned on sheet 61 (p. 121).

18 Mentioned in entry f1_1.

19 See entry 119 2, where a scribe wrote an action had been done on Wednesday (feria quarta), but it was Thursday in fact (czwartek - 'the fourth day' in Polish); similarly in entry 442 _ 1 a scribe defined a day as a Tuesday (feria tercia), but he meant Wednesday (środa - 'the middle day of a week' in Polish).

20 See e.g. entry f96v_1, where a scribe noted an action had been done in Saturday, but it was Friday; in entry f125v_4 a scribe defined a day as "Thursday, a following day after the s. Bartholomew the Apostle day" (feria quinta in crastino s. BartholomeI), whose commemoration was not on Wednesday, but on Tuesday that year.
} 
Table 1. Scribes in the manuscript

\begin{tabular}{|c|c|c|c|}
\hline Hand & Numbers of entries and their date & $\begin{array}{l}\text { Number of } \\
\text { entries }\end{array}$ & Scribe \\
\hline A & $\begin{array}{l}\text { f1_1-f4v_4 (1495-1496); f5v_1-f11_1 (1496-1497); f11v_3-f14_1 (1497); } \\
\text { f14v_2-f16_1 (1497-1498); f17_3-f18_3 (1498); f23_1 (1500); f34_1-f35v33 (1499) }\end{array}$ & 85 & $\begin{array}{c}\text { Marcin } \\
\text { of Bydgoszcz }\end{array}$ \\
\hline $\mathrm{B}$ & f5_1 (1496) & 1 & \\
\hline C & f112_2-f11v_2 (1497) & 3 & \\
\hline $\mathrm{D}$ & 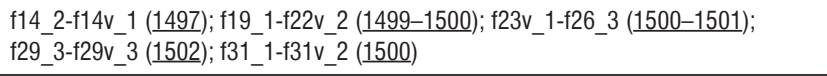 & 49 & \\
\hline $\mathrm{E}$ & $\begin{array}{l}f 16 \_2-f 16 v \_3(\underline{1498}) ; f 33 v \_2-f 33 v \_4(1499) ; f 36 \_1-f 36 \_3(1499) \\
\text { f54v_1-f55_2 }(\underline{1505}) ; f 79 v \_1(\underline{1511})\end{array}$ & 19 & \\
\hline $\mathrm{F}$ & $\begin{array}{l}\mathrm{f} 17 \_1-f 17 \_2(\underline{1498}) ; f 18 v \_1(\underline{1498}) ; f 27 v \_2-f 29 \_2(\underline{1501}) ; f 33 \_1-f 33 \_2(\underline{1498}) ; \\
f 36 v_{-} 1(\underline{1499})\end{array}$ & 13 & \\
\hline G & f26v_1-f27v_1 (1501) & 6 & \\
\hline $\mathrm{H}$ & F29v_4-f30_2 (1502); f30_4-f30v_1 (1502) & 5 & \\
\hline I & 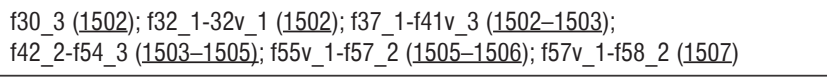 & 87 & $\begin{array}{l}\text { Tobiasz } \\
\text { Rogaliński }\end{array}$ \\
\hline J & f33v_1 (1499) & 1 & \\
\hline K & $\mathrm{f} 42 \_1$ (1508); f59v_1-f79_3 (ㅌ07-1511) & 97 & $\begin{array}{c}\text { Stefan } \\
\text { Rudawski }\end{array}$ \\
\hline $\mathrm{L}$ & f57_3 (1506) & 1 & \\
\hline M & f58_3-f59_1 (1507) & 4 & \\
\hline $\mathrm{N}$ & f80v_1-f82v_1 (1511-1512); f113_1-f116_1 (1517) & 22 & \\
\hline 0 & f82v_2-f112v_2 (1512-1517); f. 116_2-f195_1 (1518-1526) & 353 & \\
\hline
\end{tabular}

\section{Rules of this edition}

This publication proposes a new approach to the editing of historical sources, theoretical foundations of which were previously described in a number of articles, while here, it found a practical implementation $^{21}$. It does not contain a full reading of the manuscript, but at the same time it provides the user with complete text, and several tools - the result of the authors' research work - which make using the manuscript much easier. Its main purpose is

21 M. Stoń, Geoinformationssysteme (GIS) als Instrument der Quellenedition, in: Neuere Editionen der sogenannten "Ego-Dokumente" und andere Projekte in den Editionswissenschaften, Hrsg. H. Flachenecker, J. Tandecki, K. Kopiński, Toruń 2015, p. 259-270; idem, Pryncypia edytorstwa źródeł historycznych w dobie rewolucji cyfrowej, "Studia Ż́ródłoznawcze", 53, 2015, p. 155-161; idem, Sine initio et sine fine. Edycja źródła jako proces zawsze otwarty, in: Editiones sine fine, t. 1. red. K. Kopiński, W. Mrozowicz, J. Tandecki, Toruń 2017, p. 131-141; M. Stoń, M. Stomski, Edycje cyfrowe źródeł historycznych, in: Jak wydawać teksty dawne, red. K. Borowiec et al., Poznań 2017 (Staropolskie Spotkania Językoznawcze, 2), p. 65-84. to test this method of editing, both from the point of view of the authors - to test the effectiveness of works, to find the qualifications and tools needed, and to predict the possible difficulties - and from the point of view of the users. Naturally, this assessment is left to the users of the work. All feedback, both the most obvious comments, and the most critical ones is welcome. It can later be used to improve the existing edition, and - more importantly - improve the work on similar projects in the future.

Both the application of the digital tools and a departure from linear text as a main component of the edition are nothing new. What makes this project special, are its two key features. The first one is the adjustment of the method to the court books' specifics. It is important not only because of the fact that Wschowa 
court book belongs to that category, but also the overall court books' role in the diplomatic practices of the $16^{\text {th }}-18^{\text {th }}$ century Poland. It might be compared to the place the notary books held in the Mediterranean region. If we take into consideration the state of preservation of the entire source base their role appears to be even greater. The court book series, due to the character of the information they stored, their place in the legal system, and how systematically they were kept are one of the basic source corpus for the studies on the late medieval and early modern period. Some of the series continuously cover over four centuries, which corresponds to the entire existence of Polish-Lithuanian Commonwealth. Only in the area of one district the complete set of the documentation amounts to couple thousand pages which adds up to dozens million pages ever written in total. Although the preserved ones account for a number an order of magnitude smaller, they still count millions of pages. The place the series held in the state and society of that time is illustrated by the initiative of their indexing in the area of the $18^{\text {th }}$ century Galicia. There is also a need to publish such a collection of sources, though their traditional edition and reading are seen as impossible. While the sole publication does not enable an effective source query, it opens the way to elaborate the browsing tools ${ }^{22}$.

The second feature key for the project is the structure of the books, the fact that it is a closed form itself and that it contains a number of entries documenting smaller legal actions. One book usually comprised thousands of such entries, though their division, both physical - on the pages - and content-based was far from uniform. Depending on the time of elaboration and the character of the book,

22 T. Związek, Wydawać, ale jak? Propozycja cyfrowej edycji staropolskich ksiąg sądowych XV-XVIII wieku, in: Editiones sine fine, p. 203-226. there could be many entries in one page or one entry could cover a number of pages. Moreover it was a common practice to start another entry directly after the previous one, not on the next page. Some particular characteristics of the said entries can also be determined: they usually involved some kind of a form, though its content and shape was not predefined, or uniform, but rather meant a set of general data in some order connected with the entry in question. Each book comprised a great number of such forms, which often overlapped. The digital tools respond to the need of publication of such a source accounting for their aforementioned specifics.

The previous editing initiatives known to the authors of this article pursued two different avenues. One was a simple publication and dissemination of an image of a historical source, often supplemented with only some basic information. Such an approach did not lead to a significant improvement of work with the manuscript, especially when its browsing is considered. The automatic reading of the document offered some promising perspectives, however, there are no tools providing a satisfactory level of correctness, as the sources tend to be written by hand, by different scribes and thus, difficult to decipher ${ }^{23}$.

The second avenue taken was connected with supplementing the manuscript reading with some structural elements. It is worth to mention the Text Encoding Initiative, which dates back to the end of the 80 s and already ten years ago had an entire methodology and IT tool repertoire at its command and was held in high este$\mathrm{em}^{24}$. It was, however, completely useless when the handwritten manuscript in the

\footnotetext{
23 https://brandonwhawk.net/2015/04/20/ocr-and-medieval-manuscripts-establishing-a-baseline/ (access: July 7, 2018).

$24 \mathrm{http}: / /$ www.tei-c.org/index.xml (access: July 7, 2018). For the list of projects and further literature, see also https://medea.hypotheses.org/ (access: July 7, 2018).
} 
form of a scan, not a string of characters, is the subject of the edition. To tackle such sources, the tool hereby described has been devised.

A new field is being explored here. Unlike in the traditional form, utilizing the achievements of former generations, or any tried and tested solutions seems impossible. Travelling off the beaten track is inevitably connected with a great risk of losing one's way. Still, this is no justification for mistakes. The innovative nature of the publication forces a detailed explanation of the procedures accepted and followed to be provided.

There are three ways in which the contents of the source and the results of the work are presented: the tables, the GIS map, and the scans.

The two tables are the most important parts. The first one depicts the internal structure of the book and contains the list of entries found inside. Information identifying each entry (the archive, file name, page and item number) were placed in separate columns and put together in yet another column to form an entry's identifier. Final page number, serial number in the book, date presented as it appears in the source, and the heading are listed separately. All these are supplemented by the modern form of the date, identified scribe, additional remarks (e.g. that the entire text was crossed out), and the type of legal action, if it was not stated in the original heading. If another document provided with a different date is cited in a given entry, it was isolated as a separate item with the letter $a$ at the end of the identifier. Although page numbers have later been marked with a pencil, foliation, a method common in the literature, was applied. The full text of selected entries was also included in the table. These were chosen so as to present various handwritings and various types of legal actions.

The second table contains the index. Three types of headwords were singled out: geographical names, personal names, and other key terms. Surnames were listed in the form that appears in the source with additional information about the social class of the person. The letter $y$ was interpreted according to its phonetic value ([y], [ij], or [ii]), regardless of any dots above. The form, in which a given person appears for the first time in the entry (without the heading) was also given. The form of the name was not declined into Nominative: transliteration documents the standardized version found in the next column (the one used for searching the data), and at the same time provides paleographical support. The most common terms denoting the social status of a person were abbreviated, e.g. nob. - 'nobilis', gen. - 'generosus', dom. - 'dominus'. Other data, like offices held, mentioned relatives, information about death (olim), were put into a separate column. The name and surname of the husband were provided next to the name of any woman mentioned in the manuscript only by her Christian name. In order to make it possible to search for particular persons, their names were also provided in standardized form based on modern orthography, subject literature and the instructions of the Onomastics Department of Institute of Polish Language of Polish Academy of Sciences. The surname placed beside - in Nominative Singular Masculine - should help users to find members of one family.

Geographical names were provided in the form in which they appear in the source, following the same rules that applied to surnames, and identified. The unique ID allows to connect entries with the database of the settlement network in the $16^{\text {th }}$ century Poland prepared in the Atlas Department of the Institute of History of the Polish Academy of Sciences. This enables the user to find a given settlement on the basis of the forms of its name already included in the database. Depending on the region, these could be: 
modern name, $16^{\text {th }}$-century name and its variants, dictionary name (as found in the 'Historico-geographical dictionary of Polish lands in the Middle Ages'), and others. An index entry can be linked to the map by means of its identifier. Apart from settlements, the index also lists territorial units and physiographic objects, although not many of them appear in the book. However, Wschowa was not included in entries where it appears simply as the place where the court was held. Toponymic bynames, where they appear in place of a surname, were also omitted and added to the personal names index instead. However, whenever a person was mentioned as a heir of a given village, this village was included in the geographical index.

The index of key terms includes utilitarian and sacral objects. Especially in case of the former, the elements of the form and the real subject of the transaction were differentiated. General terms, like village, heirloom, or city were omitted. As such, this is a very selective index, a foundation for a more complete list, which should with time be filled with data from various source queries of Wschowa book.

The identifier of an entry connects the index table with the list of entries, as well as with the application displaying manuscript scans.

Each index entry is placed in a separate verse (record) of the database. For example, if the sotectwo in Zbarzewo (f. 11v) was the subject of a transaction, then there would be two entries: key term (sotectwo), and geographic name (Zbarzewo). Similarly, several objects, even related to one settlement and situated next to each other, were placed in separate records.

The facsimile itself is not a part of the edition, but the foundation on which it was constructed. Two layers were applied on the scans of the manuscript. The first one highlights subsequent entries. In order to simplify the form, these markings are one-dimensional, i.e. they always cover the entire width of a page, and are separated with horizontal lines. Because of this, the last, incomplete verse or heading of the subsequent entry may sometimes, partially at least, be incorrectly assigned. Still, the purpose of this layer is to show the internal structure of the entire records, so it should not make work any more difficult. Marked index entries constitute the second layer, applied on the first one. In the case of persons, name, byname and surname were marked; in the case of geographic objects, site name in noun or adjective form; in the case of key terms the appropriate term from the source was chosen. The records often stretched to a new verse. In such case, two rectangles were usually marked. However, no additional markings were used when what remained in the second verse was only the ending of a record, obviously related to the previous verse. Each term appears only once for each entry in the tables, but the manuscript also shows repetitions. They refer the user to the same record in the database. This also applies to transliteration, and, as a consequence, it may differ from what is shown on the manuscript.

All three elements - the facsimile operated by means of a special application, the GIS map, and the related tables in the database are interconnected, and each of them provides a direct link to the other two. The map, and especially the tables, allow the users to search and filter the indexes.

The division of work on the court book edition:

\section{Indexing works:}

1-20v - Marek Słoń (Institute of History, Polish Academy of Sciences),

$$
\text { 21-40v - Joanna Karczewska (Univer- }
$$
sity of Zielona Góra), 
41-60v - Michał Gochna (Institute of History, Polish Academy of Sciences),

61-80v - Tomasz Związek (Institute of History, Polish Academy of Sciences),

81-100v - Michał Słomski (Institute of History, Polish Academy of Sciences),

101-120v - Witold Brzeziński (Kazimierz Wielki University in Bydgoszcz),

121-140v - Paweł Klint (University of Wrocław),

141-160v - Arkadiusz Borek (Institute of History, Polish Academy of Sciences),

161-180v - Konrad Szuba (State Archive in Warsaw),

181-196v - Emil Kalinowski (Institute of History, University of Warsaw),

The verification of latin readings - Urszula Zachara-Związek (Institute of History, Polish Academy of Sciences).

\section{Bibliography}

Bielecka J., Inwentarze ksiag archiwów grodzkich i ziemskich Wielkopolski XIV-XVIII wieku. Województwo poznańskie, kaliskie, gnieźnieńskie, inowroctawskie, Poznań 1965.

Bielecka J., Kancelaria grodzka wielkopolska w XVIXVIII wieku, "Studia Źródłoznawcze", 1, 1957, p. 119-153.

Bielecka J., Organizacja i dziatalność kancelarii ziemskich i grodzkich wielkopolskich XIV-XVIII w., "Archeion", 22, 1954, p. 129-152.

Borek A., Granice jednostek administracji kościelnej. A: Diecezja gnieźnieńska i wtoctawska, in: Wielkopolska w drugiej potowie XVI wieku, red. K. Chłapowski, M. Słoń, Warszawa 2017 (Atlas Historyczny Polski. Mapy Szczegółowe XVI wieku, 4), p. 65-91.

Brzeziński W., Krag rodzinny kasztelana lędzkiego Wojciecha Górskiego herbu Eodzia († 1494), "Studia z Dziejów Średniowiecza”, 18, 2014, p. 15-51.

Gąsiorowski A., Początki sądów grodzkich w średniowiecznej Polsce, "Czasopismo Prawno-Historyczne”, 26 (2), 1974, p. 57-79.

Gąsiorowski A., Starostowie wielkopolskich miast królewskich $w$ dobie jagiellońskiej, Warszawa-Poznań 1981.

Gąsiorowski A., Tak zwane prawo wieczności w dawnej Polsce, "Czasopismo Prawno-Historyczne", 22 (2), 1970, p. 31-58.

Gąsiorowski A., Urzędnicy zarządu lokalnego w późnośredniowiecznej Wielkopolsce, Poznań 1970.

\section{Commentary:}

- The genesis and the course of the project - Marek Słoń (Institute of History, Polish Academy of Sciences);

- The source commentary - Witold Brzeziński (Kazimierz Wielki University in Bydgoszcz), Urszula Zachara-Związek (Institute of History, Polish Academy of Sciences), Krisztina Rábai (University of Szeged);

- Identification of scribes - Joanna Karczewska (University of Zielona Góra);

- Rules of the edition - Marek Słoń (Institute of History, Polish Academy of Sciences).

\section{Translated by Paulina Wactawik}

Gochna M., Granice państwowych jednostek terytorialnych, in: Wielkopolska w drugiej potowie XVI wieku, red. K. Chłapowski, M. Słoń, Warszawa 2017 (Atlas Historyczny Polski. Mapy Szczegółowe XVI wieku, 4), p. 46-64.

Łosowski J., Akta sądów i urzędów szlacheckich w XIVXVIII wieku, in: Dyplomatyka staropolska, red. T. Jurek, Warszawa 2015, p. 253-338.

Łosowski J., Kancelaria grodzka chetmska od XV do XVIII wieku. Studium o urzędzie, dokumentacji, jej formach $i$ roli $w$ życiu społeczeństwa staropolskiego, Lublin 2004.

Słoń M., Słomski M., Edycje cyfrowe źródet historycznych, in: Jak wydawać teksty dawne, red. K. Borowiec et al., Poznań 2017 (Staropolskie Spotkania Językoznawcze, 2), p. 65-84.

Słoń M., Geoinformationssysteme (GIS) als Instrument der Quellenedition, in: Neuere Editionen der sogenannten "Ego-Dokumente" und andere Projekte in den Editionswissenschaften, Hrsg. H. Flachenecker, J. Tandecki, K. Kopiński, Toruń 2015, p. 259270.

Słoń M., Pryncypia edytorstwa źródet historycznych $w$ dobie rewolucji cyfrowej, "Studia Źródłoznawcze", 53, 2015, p. 155-161.

Słoń M., Sine initio et sine fine. Edycja źródta jako proces zawsze otwarty, in: Editiones sine fine, t. 1, red. K. Kopiński, W. Mrozowicz, J. Tandecki, Toruń 2017, p. 131-141. 
Stownik historyczno-geograficzny ziem polskich $w$ średniowieczu, red. T. Jurek (http://www.slownik.ihpan. edu.pl/index.php, access: April 24, 2018).

Wojciechowska Z., Ksiegi sądowe wielkopolskie z okresu I Rzeczypospolitej w zasobie Archiwum Państwowego w Poznaniu, "Poznański Rocznik Archiwalno-Historyczny”, 5, 1998, p. 11-32.

\section{Summary}

The article proposes a new method of source edition presented on the example of the first Wschowa court book. The book comprises the entries from the end of the $15^{\text {th }}$ and the beginnings of the $16^{\text {th }}$ century and amounts to nearly 200 sheets of the manuscript. The essence of the method is presentation of the source itself and the effects of work of the authors on the three interconnected layers: scan of the book, two attribute tables, and GIS map. The edition was elaborated with use of the INDXr application. The process of elaboration involved adding two layers to the digitised facsimile of the manuscript. The layers correspond to the two aforementioned tables in the database, which are the key part of the edition. The table
Ziemie polskie Korony w XVI w. Przestrzenna baza danych, Instytut Historii PAN im. Tadeusza Manteuffla (http://atlasfontium.pl, access: May 24, 2018).

of entries contains their list along some basic information on each of them (unique ID, the page scope, heading, date, comments) and a full reading of chosen entries. The second one - index table - contains the personal and geographical names as well as key terms indexes. The key terms are given in their source form, the names were normalised and geographical places were matched with ID keys connecting them with a database of Poland's settlement network in the $16^{\text {th }}$ century, which together enabled filtering and browsing the information. Such a method of presentation of the source content appears particularly useful in dissemination of the mass sources, which are the medieval and early modern court books.

Keywords: Wschowa, source edition, court book, digital humanities, $15^{\text {th }}$ century, $16^{\text {th }}$ century

Marek Słoń - Department of Historical Atlas, Institute of History, Polish Academy of Sciences (marek.slon@wp.pl)

Urszula Zachara-Związek - Department of Historical Atlas, Institute of History, Polish Academy of Sciences (uzwiazek@ihpan.edu.pl)

Arkadiusz Borek - Department of Historical Atlas, Institute of History, Polish Academy of Sciences

Witold Brzeziński - Faculty of Philosophy of Education and Social Education, Kazimierz Wielki University in Bydgoszcz

Michał Gochna - Department of Historical Atlas, Institute of History, Polish Academy of Sciences

Emil Kalinowski - Department of Early Modern History, Institute of History, University of Warsaw

Joanna Karczewska - Department of Auxillary Sciences and Archival Studies, Institute of History, University of Zielona Góra

Paweł Klint - Department of Historical Anthropology, Institute of History, University of Wrocław

Krisztina Rábai - Institute of History, Department of Auxiliaries to the Study of History, University of Szeged

Michał Słomski - Department of Historical Atlas, Institute of History, Polish Academy of Sciences

Konrad Szuba - State Archive in Warsaw

Tomasz Związek - Department of Historical Atlas, Institute of History, Polish Academy of Sciences 